\title{
Evaluation of Herbicidal Efficacy for Management of Isoproturon-Resistant Phalaris minor
}

\author{
Prinsa*, Hem C. Joshi and S.K. Guru \\ Department of Plant Physiology, G.B.P.U.A.\&T. Pantnagar-263145, U. S. Nagar, \\ Uttarakhand, India \\ *Corresponding author
}

\begin{tabular}{|c|c|}
\hline & A B S T R A C T \\
\hline $\begin{array}{l}\text { Phalaris minor, } \\
\text { Resistance, } \\
\text { Herbicide treatments, } \\
\text { POE- post } \\
\text { emergence } \\
\text { herbcicide, MOAs- } \\
\text { Mode of actions }\end{array}$ & \multirow{3}{*}{$\begin{array}{l}\text { Widespread resistance in Phalaris minor is a major challenge for sustainable productivity. } \\
\text { Recent increases in the development of herbicide resistance in Phalaris minor worldwide } \\
\text { demand a high up strategies to control this weed. Herbicide-resistant weeds are a } \\
\text { constraint to weed management. The use of potential management strategies is crucial in } \\
\text { assuring sustainable production. A pot-culture experiment was conducted during the winter } \\
\text { season of } 2017-18 \text { with the objective to evaluate the herbicidal efficacy for management of } \\
\text { isoproturon-resistant Phalaris minor. Post-emergence herbicides used in this study were } \\
\text { clodinafop -propargyl, metribuzin, sulfosulfuron, pinoxaden and Halauxifen methyl } \\
+ \text { Pyroxsulam. Increased doses (up to } 1.5 \mathrm{X} \& 2.0 \mathrm{X} \text { ) of herbicide provided effective control } \\
\text { of } P \text {. minor. However, application of recommended dose (1.0X) of metribuzin provides a } \\
\text { satisfactory control of } P \text {. minor. These findings suggest that post-emergence herbicide } \\
\text { controls resistant } P \text {. minor and delay further herbicide resistance in this weed. }\end{array}$} \\
\hline Article Info & \\
\hline $\begin{array}{l}\text { Available Online: } \\
\text { 10 December } 2018\end{array}$ & \\
\hline
\end{tabular}

\section{Introduction}

In recent past, herbicide resistance has emerged as the greatest concern of contemporary agriculture which relies primarily on synthetic inputs for its sustainability (Petit et al., 2010). Littleseed canarygrass (Phalaris minor Retz.), the most troublesome weed of wheat crop has developed resistance against isoproturon in North-Western Indo-Gangetic plains of India. The frequent use of herbicides with the same mode of action is the prime contributing factor in the fast evolution of herbicide resistance
(Beckie, 2006; Norsworthy et al., 2012). Resistance of littleseed canary grass to isoproturon was first reported in India during 1995 (Malik and Singh, 1995). Isoproturon is a substituted urea herbicide was recommended for control of $P$. minor in wheat, and was largely accepted by the Indian farmers (Gill et al., 1978). Two major mechanism of herbicide resistance i.e. target site modification and enhance metabolism. The target site modification is well understood in P. minor, the insensitive target enzyme based resistance mechanism is understood (Tal et al., 1996). 
It is difficult to deny the importance of herbicides to modern crop production. Herbicides are most effective and economic tool among the weed management practices. Sometimes herbicide treatment affects the photosynthetic process in multiple ways. There is a general consensus that PSII is the main target for heat mediated disturbances of the photosynthetic electron transport (Havaux et al., 1991), and in particular the functionality of the oxygen evolving complex (OEC) is affected (Nash et al., 1985).In some areas, herbicides have become the only means by which weeds are controlled, leading to widespread HR by means of increasingly powerful and complex resistance mechanisms (Powles and Yu, 2010; Powles, and Gaines, 2016). Use of herbicide is rapidly increasing in the world including India (Kumar et al., 2018). The aims of this study were the establishment of a reliable and consistent screening procedure for the measurement of herbicides at different doses on biochemical analysis of isoproturon resistance Phalaris minor.

\section{Materials and Methods}

The isoproturon resistance seeds were collected from the Crop Research Centre, GBPUA\&T Pantnagar and they were subjected to grow in pots in Ravi season of 2017-18. After germination, the twenty seedlings were maintained in each pot. The experiment was laid out in randomized block design. The table 1 showing list of the treatments studied in this experiment. The following post-emergence herbicides were applied at 30 days after sowing.

For control of isoproturon-resistant Phalaris minor, various herbicides were evaluated under pot experiments and one set of replication is kept as a control. The plants that remained unsprayed with herbicide served as control. Observations were recorded after of seven days of spraying on weed mortality. Percentage mortality was calculated by the formula; no. of plants that survived after $\mathrm{x}$ days/ no. of plants at the time of spray. The treatments that showed mortality in the range of $70-100 \%$ were classified as most effective, those that showed mortality in the range of 35$70 \%$ were classified as medium and those in the range of $0-35 \%$ as least effective treatments.

Various physiological and biochemical aspect of the weed under study were characterized. Chlorophyll estimation was done by the Dimethyl sulphoxide (DMSO) extraction method of Hiscox and Isralestam (1979), proline and protein content from leaves samples were examined by the method given by Bates et al., (1973) and Bradford, (1976) respectively. Lipid peroxidation was determined by measuring the amount of MDA produced by the thiobarbituric acid reaction as described by Heath and Packer, 1968. Membrane stability index was examined according to Sairam et al., 1997. Hydrogen peroxide content and total phenol content were estimated by Alexieva et al., 2001 and Swain and Hillis, 1959 method respectively.

The data obtained from field trials during the course of present investigation were analyzed statistically by using randomized block design (RBD). Standard error of means (S.E.m \pm ) and critical difference $(\mathrm{CD})$ was evaluated at $5 \%$ level of significance by following standard statistical procedure.

\section{Results and Discussion}

Mortality (\%) of $P$. minor treated with herbicides

Data on mortality (\%) of $P$. minor plant treated with different doses of post-emergence herbicide is presented in figure 1. Mortality was recorded at different time intervals after 
spraying. The rate of mortality increased with increasing doses of post-emergence herbicides. The mortality rate was highest in the Metribuzin (T6) treatment which ranged from $85.0 \%$ at 5DAS to $100 \%$ within 10 days after spraying. Whereas, Clodinafop-propargyl (T1) treatment had minimum $(33.3 \%)$ percent mortality but simultaneously the T3 Clodinafop-propargyl (2X) treatment almost doubled the mortality rate $(93.3 \%)$ by doubling its recommended dose. Likewise, the Halauxifen methyl +Pyroxsulam (T9) treatment had $46.7 \%$ mortality, which increased up to $80.0 \%$ in T11 Halauxifen methyl +Pyroxsulam (2X) treatment.

\section{Effect of post-emergence herbicides (POE) on chlorophyll content (mg/g FW)}

Chlorophyll content was estimated at different time intervals after application of post emergence herbicides. The T12 Control treatment had significantly higher amount of chlorophyll a, chlorophyll b and total chlorophyll content.

The application of herbicides effectively reduced the chlorophyll content in all the treatments accordingly. The chlorophyll content was gradually decreased under herbicide treatment after application. Minimum value of chlorophyll ' $a$ ' content was recorded in metribuzin (T6) treatment which ranged from $0.470 \mathrm{mg} / \mathrm{g} \mathrm{FW}$ at 1DAS to 0.201 $\mathrm{mg} / \mathrm{g}$ FW at 7DAS.

Among the herbicides, Halauxifen methyl +Pyroxsulam (T9) showed highest amount of chlorophyll b (1.583 mg/g FW at 1DAS and $0.774 \mathrm{mg} / \mathrm{g}$ FW at 7DAS) while the Metribuzin (T6) treatment had minimum which ranged from $0.364 \mathrm{mg} / \mathrm{g} \mathrm{FW}$ at 1DAS to $0.151 \mathrm{mg} / \mathrm{g} \mathrm{FW}$ 7DAS respectively. Similar pattern of total chlorophyll content reduction was followed by herbicide treatments as in case of chlorophyll a (Fig. 2-4).
Effect of post-emergence (POE) herbicides on protein content $(\mathrm{mg} / \mathrm{g})$ of isoproturonresistant $P$. minor

Effect of herbicides on the protein content (mg/g) of isoproturon-resistant $P$. minor is presented in figure 5. The protein content was higher in control condition as compared to the herbicide treatments. Nevertheless, among herbicides, Halauxifen methyl +Pyroxsulam (T9) showed higher amount of protein content and it was $0.232 \mathrm{mg} / \mathrm{g}$ at 3DAS which decreased to $0.120 \mathrm{mg} / \mathrm{g}$ at 7DAS respectively. Minimum protein content was observed in Metribuzin treatment (T6); it was $0.034 \mathrm{mg} / \mathrm{g}$ at 3DAS which decreased to 0.017 $\mathrm{mg} / \mathrm{g}$ at 7DAS. The higher doses of clodinafop, sulfosulfuron, pinoxaden and Halauxifen methyl +Pyroxsulam treatments accumulated lesser amount of protein content then the $1 \mathrm{X}$ recommended doses.

\section{Effect of herbicides on proline content of isoproturon-resistant $P$. minor}

Effect of herbicides on the proline content $(\mu$ mol g ${ }^{-1} \mathrm{FW}$ ) of isoproturon-resistant $P$. minor is presented in following table 2 . The proline content was higher in all the herbicide treatments as compared to control situation. Nevertheless, among herbicides, Halauxifen methyl +Pyroxsulam (T9) accumulated lesser amount of proline which ranged from $0.56 \mu$ mol g ${ }^{-1} \mathrm{FW}$ at $3 \mathrm{DAS}$ to $2.65 \mu \mathrm{mol} \mathrm{g}{ }^{-1} \mathrm{FW}$ at 7DAS. Maximum proline content was estimated in Metribuzin treatment (T6); it was $2.19 \mu \mathrm{mol} \mathrm{g}{ }^{-1} \mathrm{FW}$ at 3DAS which increased up to $13.40 \mu \mathrm{mol} \mathrm{g}^{-1} \mathrm{FW}$ at 7DAS. The higher doses of clodinafop, sulfosulfuron, pinoxaden and Halauxifen methyl +Pyroxsulam treatments accumulated higher amount of proline content then the $1 \mathrm{X}$ recommended dose i.e., Clodinafop-propargyl treatment (T1) had $3.84 \mu \mathrm{mol} \mathrm{g}^{-1} \mathrm{FW}$ proline content whereas T3 Clodinafop-propargyl 2.0X recorded 5.65 $\mu \mathrm{mol} \mathrm{g}{ }^{-1} \mathrm{FW}$ at 7DAS. Likewise, 
Sulfosulfuron treatment (T4) carried $3.90 \mu$ mol $\mathrm{g}^{-1} \mathrm{FW}$ and $\mathrm{T} 5$ Sulfosulfuron $1.5 \mathrm{X}$ recorded $5.31 \mu \mathrm{mol} \mathrm{g}{ }^{-1} \mathrm{FW}$ proline content.

Effect of herbicides on MDA content ( $\mu$ mol MDA $g^{-1} \mathbf{F W}$ ) of isoproturon-resistant $P$. minor

Effect of different post emergence herbicides on MDA content ( $\mu$ mol MDA $\left.\mathrm{g}^{-1} \mathrm{FW}\right)$ of isoproturon-resistant $P$. minor was assessed at different time intervals after applications. Results indicated a significant increase in the MDA content in all the herbicide treatments as compared to the control condition. Metribuzin treatment (T6) accumulated maximum MDA content $(0.639 \mu$ mol MDA $\mathrm{g}^{-1} \mathrm{FW}$ ) after 1 day of application followed by Pinoxaden (T8) treatment $(0.596 \mu$ mol MDA $\mathrm{g}^{-1} \mathrm{FW}$ ) and Clodinafop-propargyl (T3) treatment $\left(0.499 \mu\right.$ mol MDA $\left.\mathrm{g}^{-1} \mathrm{FW}\right)$. Notably the level of MDA content increased in response to the higher doses as well as duration of application. Control condition showed lesser amount of MDA content which ranged from $0.075 \mu$ mol MDA $\mathrm{g}^{-1} \mathrm{FW}$ at 1DAS to $0.189 \mu$ mol MDA $\mathrm{g}^{-1} \mathrm{FW}$ 7DAS (Fig. 6).

\section{Effect of herbicides on $\mathrm{H}_{2} \mathrm{O}_{2}$ content ( $\mu$ mol} $\mathrm{g}^{-1} \mathrm{FW}$ ) of isoproturon-resistant $P$. minor

Effect of POE herbicides on the $\mathrm{H}_{2} \mathrm{O}_{2}$ content $\left(\mu \mathrm{mol} \mathrm{g} \mathrm{g}^{-1} \mathrm{FW}\right)$ of isoproturon-resistant $P$. minor was assessed at different time intervals and it is presented in following figure 7 . Maximum $\mathrm{H}_{2} \mathrm{O}_{2}$ content was observed in Metribuzin (T6) treatment $\left(384.7 \mu \mathrm{mol} \mathrm{g}{ }^{-1}\right.$ FW) followed by T8 Pinoxaden $(344.5 \mu \mathrm{mol}$ $\left.\mathrm{g}^{-1} \mathrm{FW}\right)$ and $\mathrm{T} 7$ Pinoxaden treatment $(333.5 \mu$ mol $\mathrm{g}^{-1} \mathrm{FW}$ ) after 7 days of application. The results indicated that $\mathrm{H}_{2} \mathrm{O}_{2}$ content was gradually increased in response to the higher doses of clodinafop, sulfosulfuron, pinoxaden and Halauxifen methyl +Pyroxsulam treatments. Moreover among herbicides, Halauxifen methyl +Pyroxsulam (T9) carried lowest amount of $\mathrm{H}_{2} \mathrm{O}_{2}$ content which ranged from $97.4 \mu \mathrm{mol} \mathrm{g}^{-1} \mathrm{FW}$ at 1DAS $186.8 \mu \mathrm{mol}$ $\mathrm{g}^{-1} \mathrm{FW}$ at $7 \mathrm{DAS}$.

Table.1 List of treatments for pot culture experiment

\begin{tabular}{|l|l|l|l|}
\hline Symbol & Treatments & Dose g a.i./ha & Application time \\
\hline T1 & Clodinafop-propargyl & 60 & Post-emergence \\
\hline T2 & Clodinafop-propargyl (1.5X) & 90 & Post-emergence \\
\hline T3 & Clodinafop-propargyl (2X) & 120 & Post-emergence \\
\hline T4 & Sulfosulfuron & 25 & Post-emergence \\
\hline T5 & Sulfosulfuron $(1.5 X)$ & 37.5 & Post-emergence \\
\hline T6 & Metribuzin & 210 & Post-emergence \\
\hline T7 & Pinoxaden & 50 & Post-emergence \\
\hline T8 & Pinoxaden $(1.5 X)$ & 70 & Post-emergence \\
\hline T9 & Halauxifen methyl +Pyroxsulam & 60 & Post-emergence \\
\hline T10 & Halauxifen methyl +Pyroxsulam (1.5X) & 90 & Post-emergence \\
\hline T11 & Halauxifen methyl +Pyroxsulam (2X) & 120 & Post-emergence \\
\hline T12 & Control & - & - \\
\hline
\end{tabular}


Table.2 Effect of different types and doses of herbicides on proline content ( $\mu$ mol g $\left.{ }^{-1} \mathrm{FW}\right)$ of isoproturon-resistant $P$. minor at different time interval

\begin{tabular}{|l|c|c|c|}
\hline \multicolumn{4}{|c|}{ Proline content $\left(\mu \mathrm{mol} \mathrm{g}^{-1} \mathrm{FW}\right)$ of isoproturon-resistant $P$. minor } \\
\hline \multicolumn{1}{|c|}{ Treatments } & 3DAS & 5DAS & 7DAS \\
\hline T1 Clodinafop-propargyl & 0.88 & 2.32 & 3.84 \\
\hline T2 Clodinafop-propargyl $(1.5 \mathrm{X})$ & 1.16 & 2.71 & 4.22 \\
\hline T3 Clodinafop-propargyl (2X) & 1.56 & 3.32 & 5.65 \\
\hline T4 Sulfosulfuron & 0.80 & 2.21 & 3.90 \\
\hline T5 Sulfosulfuron (1.5X) & 1.29 & 2.73 & 5.31 \\
\hline T6 Metribuzin & 2.19 & 7.66 & 13.40 \\
\hline T7 Pinoxaden & 1.54 & 3.41 & 7.62 \\
\hline T8 Pinoxaden (1.5X) & 1.93 & 3.94 & 8.60 \\
\hline T9 Halauxifen methyl +Pyroxsulam & 0.56 & 1.71 & 2.65 \\
\hline T10 Halauxifen methyl +Pyroxsulam (1.5X) & 0.91 & 2.09 & 3.13 \\
\hline T11 Halauxifen methyl +Pyroxsulam (2X) & 1.22 & 2.58 & 4.35 \\
\hline T12 Control & 0.38 & 1.54 & 2.90 \\
\hline S.Em \pm & 0.08 & 0.13 & 0.31 \\
\hline CD at 5\% & 0.25 & 0.43 & 0.96 \\
\hline
\end{tabular}

DAS- days after spraying, X-recommended doses, POE- post-emergence herbicide

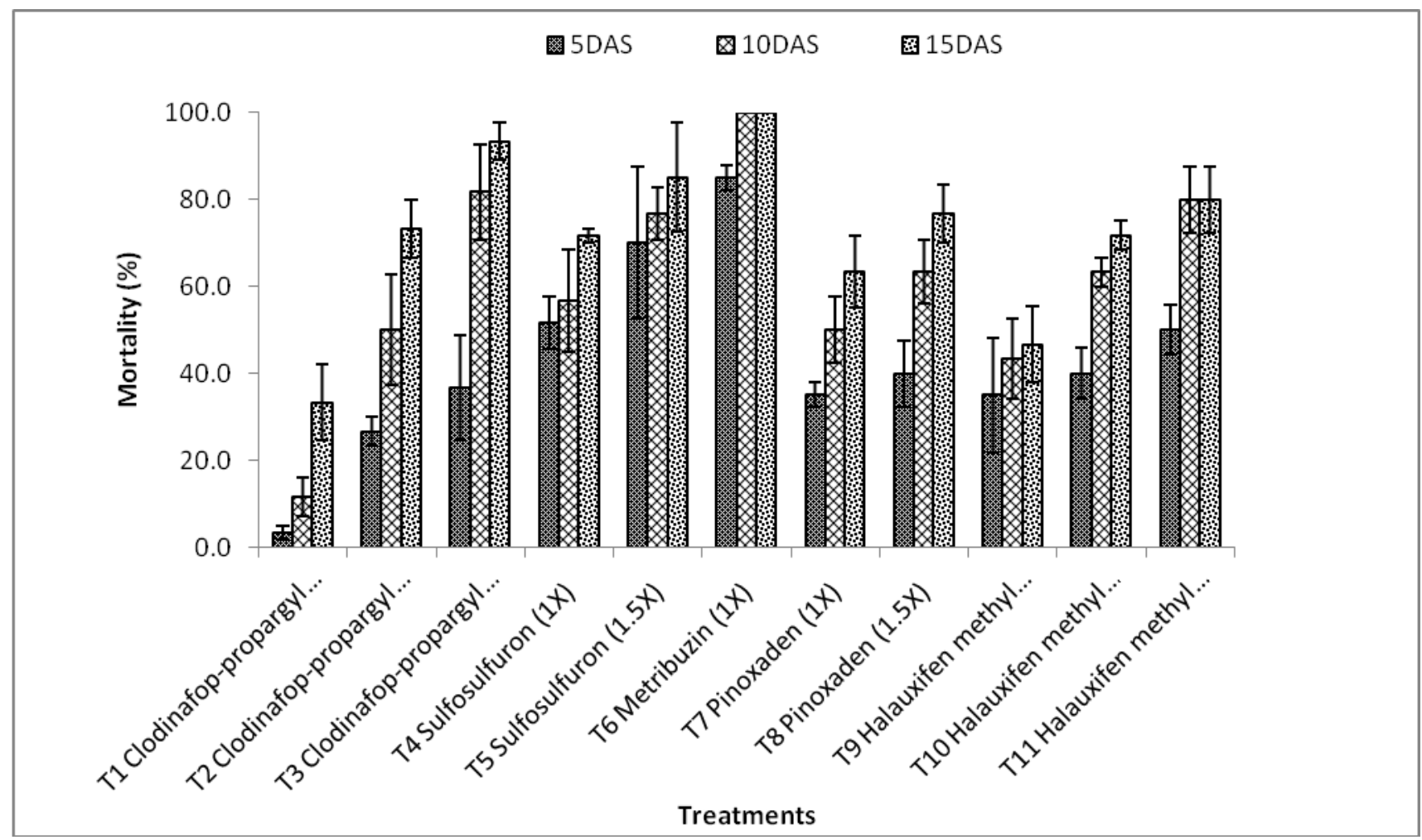

Fig.1 Effect of different types and doses of herbicides on mortality (\%) of isoproturon-resistant Phalaris minor 


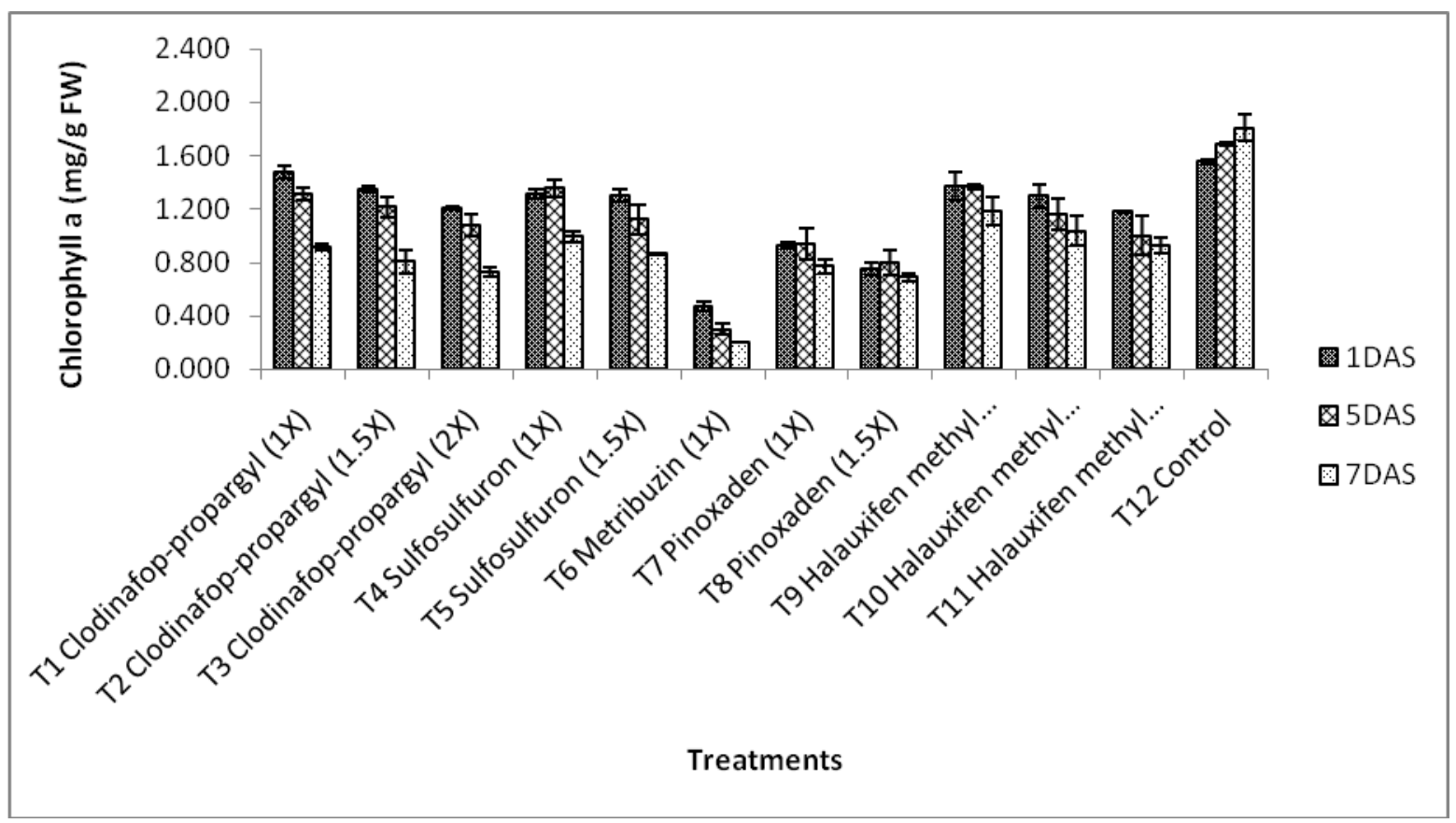

Fig.2 Effect of different types and doses of herbicides on chlorophyll 'a' content $\left(\mathrm{mg} \mathrm{g}^{-1} \mathrm{FW}\right)$ of isoproturon-resistant $P$. minor at different time interval

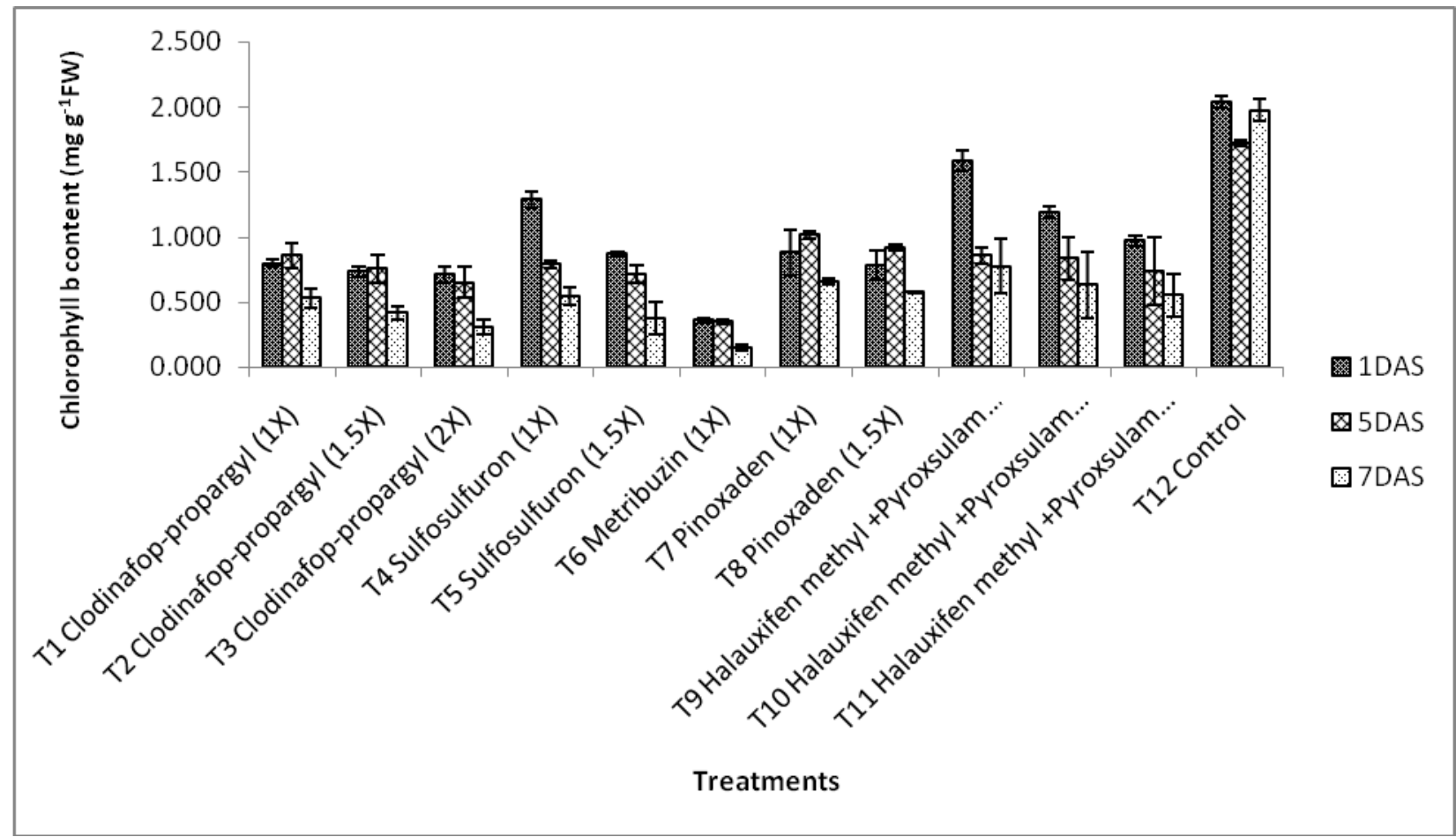

Fig.3 Effect of different types and doses of herbicides on chlorophyll ' $b$ ' content $\left(\mathrm{mg} \mathrm{g}^{-1} \mathrm{FW}\right)$ of isoproturon-resistant $P$. minor at different time interval 


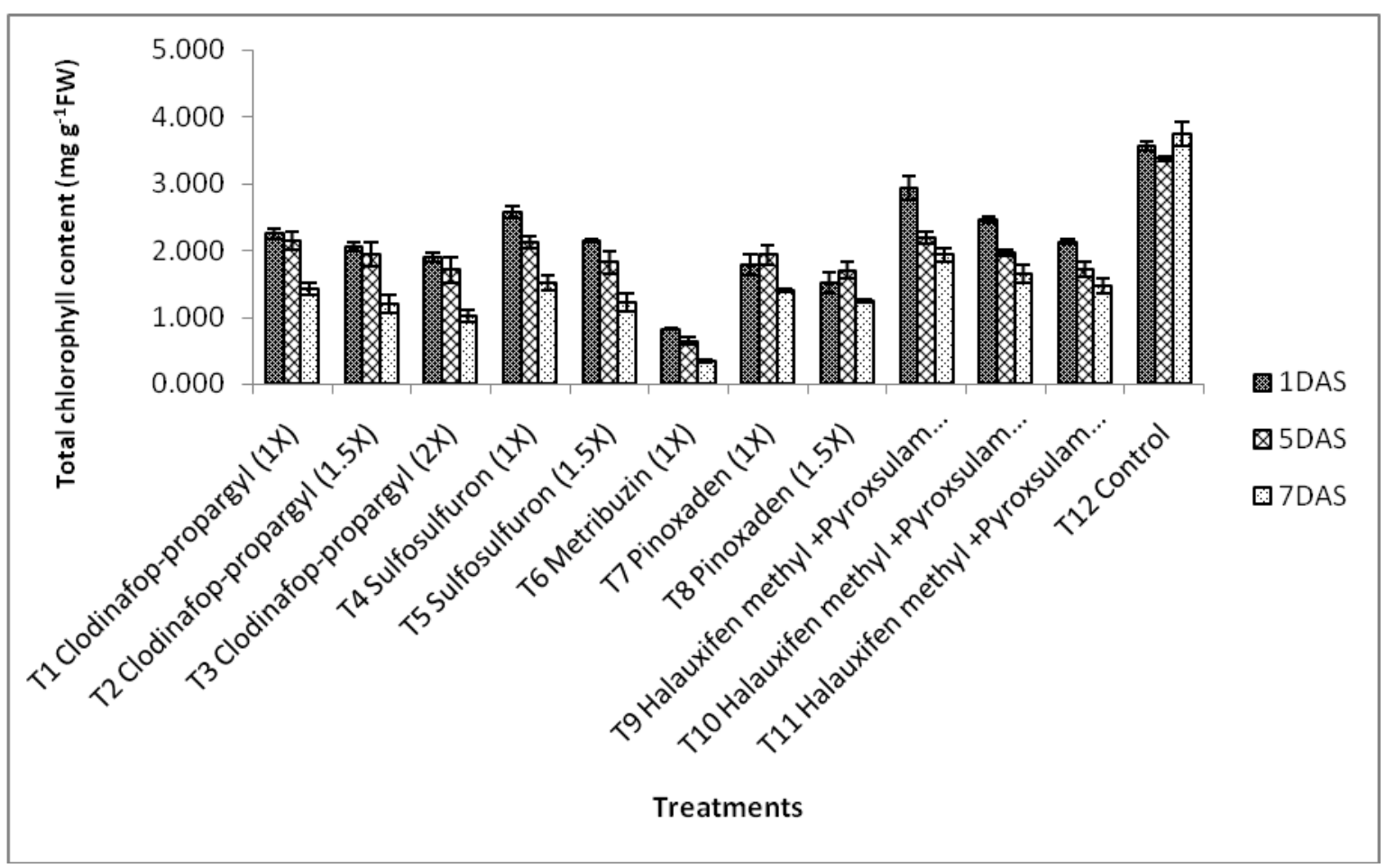

Fig.4 Effect of different types and doses of herbicides on total chlorophyll content $\left(\mathrm{mg} \mathrm{g}^{-1} \mathrm{FW}\right)$ of isoproturon-resistant $P$. minor at different time interval

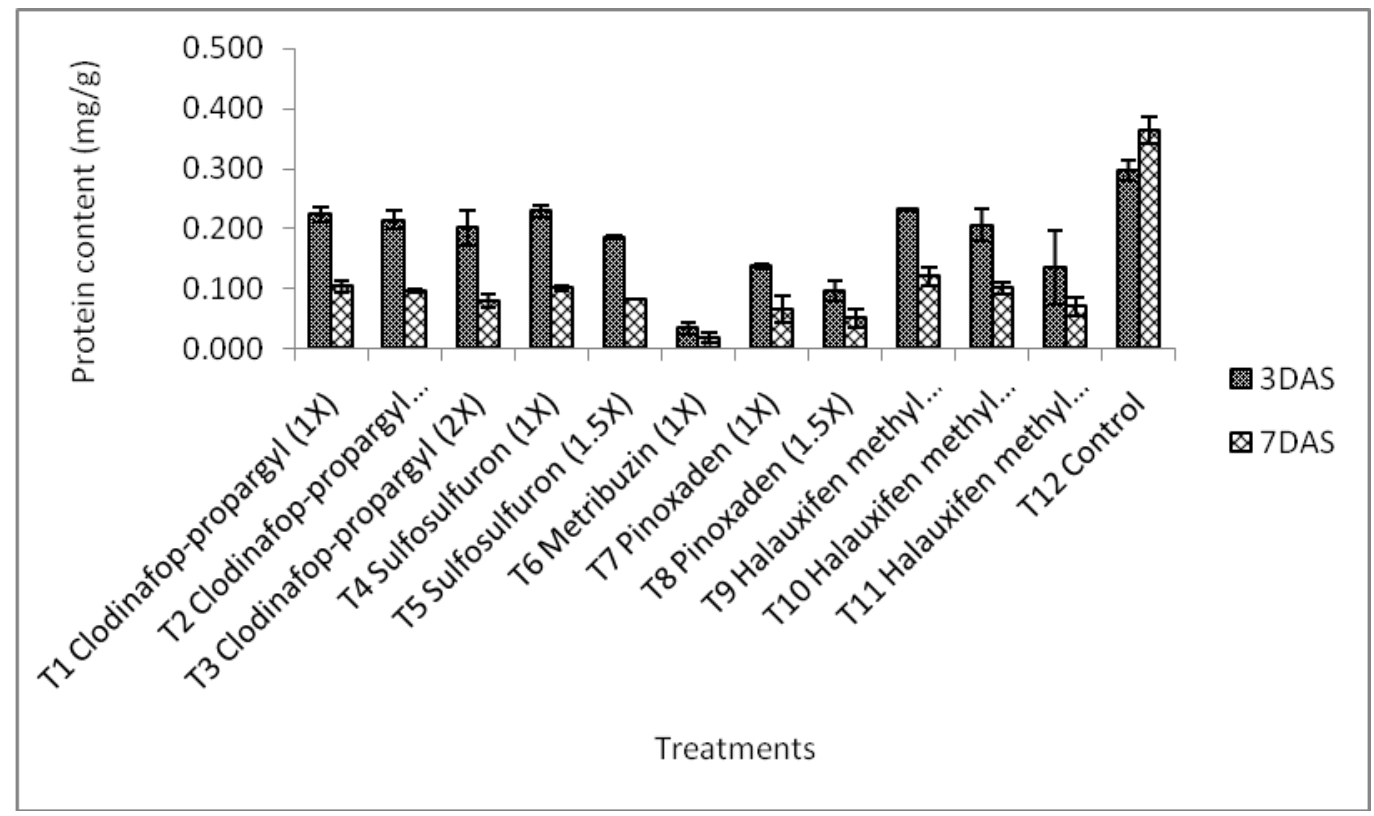

Fig.5 Effect of different types and doses of herbicides on protein content (mg/g) of isoproturonresistant $P$. minor 


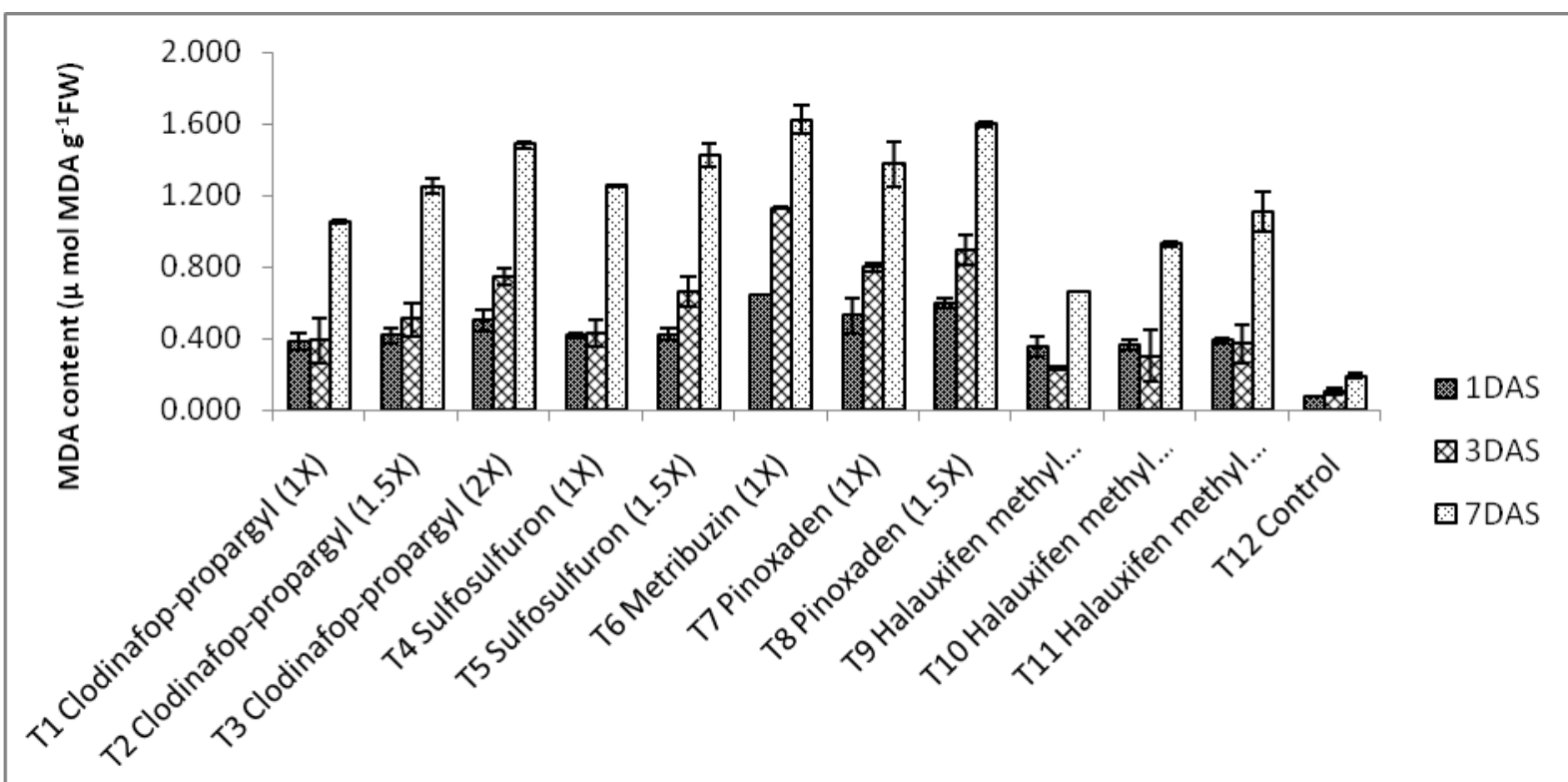

Treatments

Fig.6 Effect of different types and doses of herbicides on MDA content ( $\mu$ mol MDA g $\left.{ }^{-1} \mathrm{FW}\right)$ of isoproturon-resistant $P$. minor at different time interval

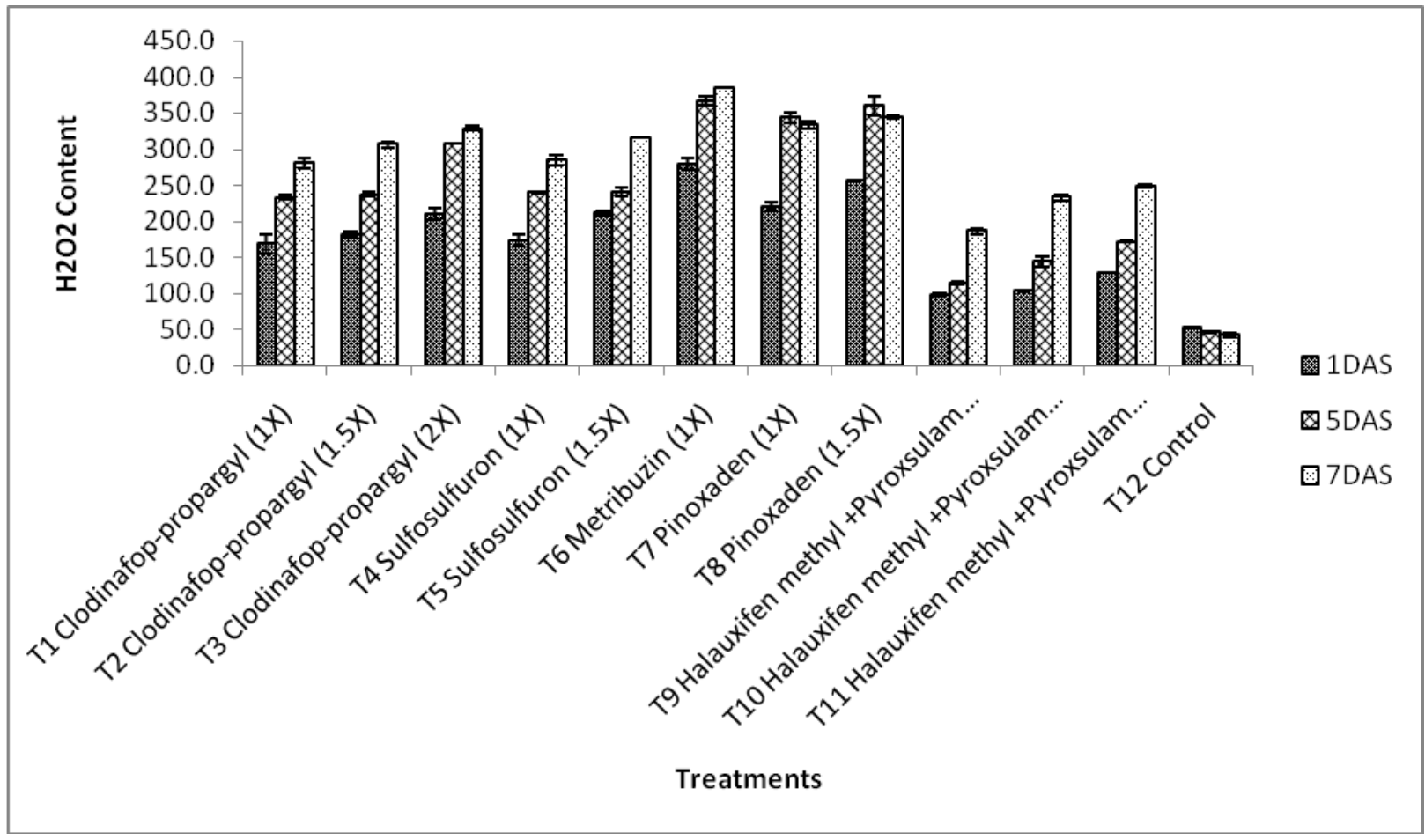

Fig.7 Effect of different types and doses of herbicides on $\mathrm{H}_{2} \mathrm{O}_{2}$ content $\left(\mu\right.$ mol g $\left.{ }^{-1} \mathrm{FW}\right)$ of isoproturon-resistant $P$. minor 


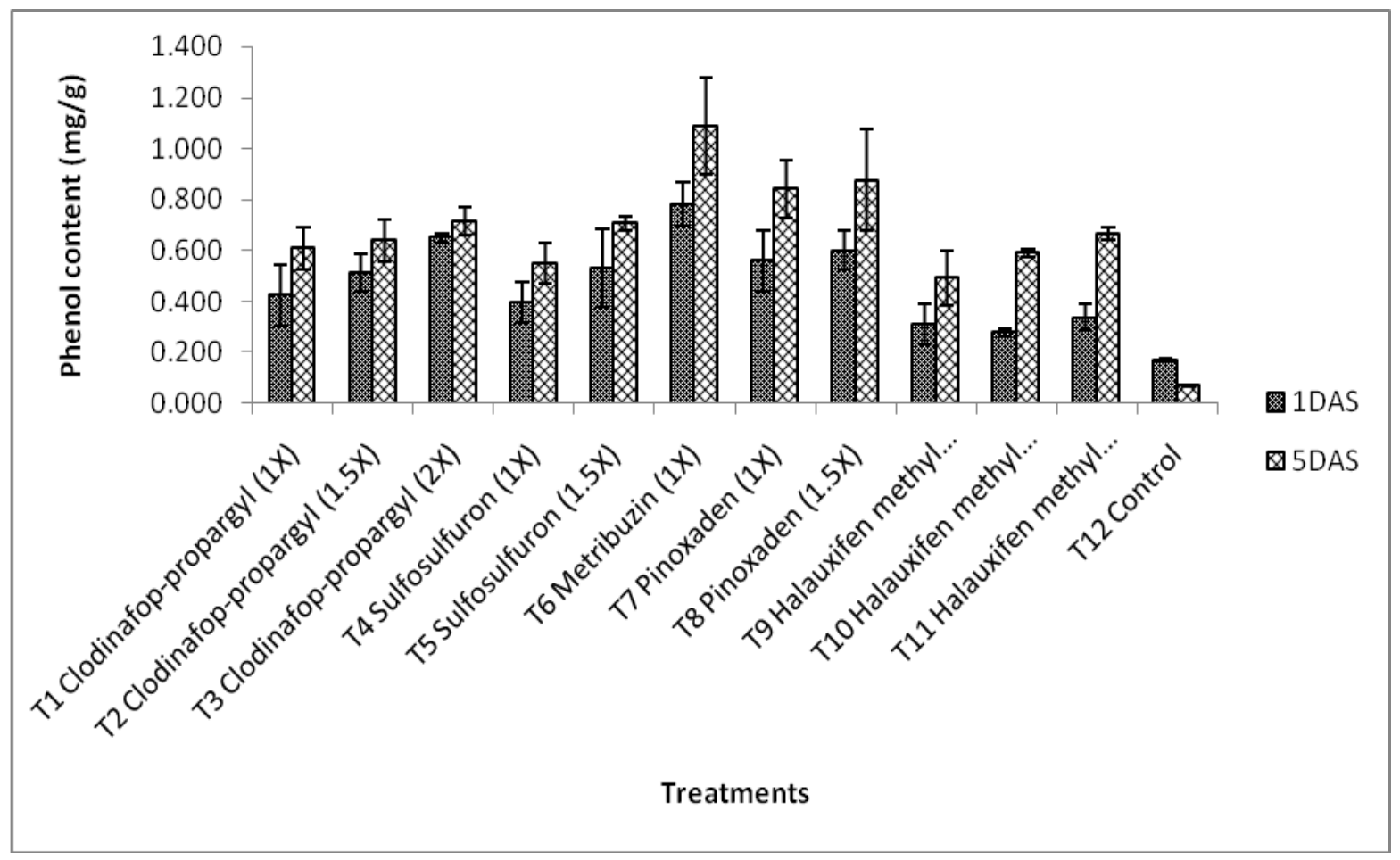

Fig.8 Effect of different types and doses of herbicides on Phenol content $(\mathrm{mg} / \mathrm{g})$ of isoproturonresistant $P$. minor

Effect of herbicides on Phenol content $(\mathrm{mg} / \mathrm{g})$ of isoproturon-resistant $P$. minor

Effect of herbicides on Phenol content $(\mathrm{mg} / \mathrm{g})$ of isoproturon-resistant $P$. minor was estimated at 1 and 5DAS and it is presented in following figure 8 . Among the herbicides, Metribuzin (T6) treatment accumulated maximum amount of phenol content at different time intervals which ranged from $0.782 \mathrm{mg} / \mathrm{g}$ at $1 \mathrm{DAS}$ to $1.089 \mathrm{mg} / \mathrm{g}$ at $5 \mathrm{DAS}$. Minimum phenol content was recorded in control condition.

The different doses of any herbicide respond differently in a plant system. Sometime the recommended dose of a herbicide provide better efficacy e.g., increased dose of halauxifen methyl +pyroxsulam up to $2.0 \mathrm{X}$ was not effectual as 1.0X dose of metribuzin. Application of increased doses of some herbicides by 1.5 and 2.0 times of recommended doses showed effective control over the growth of Phalaris minor whereas the recommended dose of metribuzin was enough to control the weed. A decline in chlorophyll content after application of herbicides has been reported in $P$. minor. In present study, the control treatment had significantly higher amount of chlorophyll content. An increased dose of herbicides for clodinafop, sulfosulfuron, pinoxaden and palauxifen methyl +Pyroxsulam decreases the chlorophyll value simultaneously. Minimum value of chlorophyll a was recorded in metribuzin treatment (T6). The content of photosynthetic pigments provides clues for their impact on biomass accumulation (Singh et al., 2010).

When a plant is subjected to stress condition, it accumulates proline which indicates the stress level in plant cell. Stress results in alterations in cell membranes due to production of reactive oxygen species and lipid peroxidation. Results indicated a 
significant increase in the proline content in all the herbicide treatments. MDA content was significantly higher $(p<0.05)$ in all the treatments as compared to control. Similar results were reported by Dhawan et al., (2012) where increase in proline content was recorded in herbicide treated $P$. minor plant. Proline acts as osmoprotectant playing important roles in protection of subcellular structures, enzymes, and increasing cellular turgor pressure that provides the necessity for cell expansion under stress conditions.

Controlling weeds in the field using herbicides with different MOAs in rotations, mixtures, and sequential applications can avoid and delay the development of herbicide resistance (Norsworthy et al., 2012). Thus, post-emergence grass herbicides are commonly used to control this grassy weed in wheat. Effective control of isoproturonresistant little seed canarygrass with alternate herbicides have been reported by Chhokar and Malik (2002). The immediate option to curtail resistance evolution is to use alternative herbicides in rotation with other agronomic practices to attain sustainable production.

In conclusions, herbicide resistance is an alarming issue which is increasing throughout the worldwide. Continuous use of the same herbicide or herbicides having same mechanism of action has been the major causes of herbicide resistance. Frequent and repeated application of same herbicide over several seasons in a same area exerts selection pressure on resistant individual to evolve. Thus, understanding the physiological impact and mode of action of any herbicide on Phalaris minor and using the inherent resistant potential of natural genetic diversity to withstand even higher than the recommended doses of herbicide should be an essential component of scientific research.

\section{Acknowledgements}

The authors duly acknowledge the help and support of Department of Plant Physiology, CBSH GBPUA\&T as well as ICAR AICRP (Weed management) regarding all the research related facilities.

\section{References}

Alexieva, V., Sergio, I., Mapelli, S. and Karanov, E. 2001. The effect of drought and ultraviolet radiation on growth and stress markers in pea and wheat. Plant Cell Environ. 24: 1337-1344.

Bates, L. S., Waldran, R. P. and Teare, I. D. 1973. Rapid determination of free proline for water studies. Plant Soil. 39: 205-208.

Beckie, H.J. 2006. Herbicide-resistant weeds: management tactics and practices. Weed Technol. 20: 793-814.

Bradford, M. 1976. A rapid and sensitive method for the quantification of microgram quantities of protein utilizing the principal of protein dye binding. Anal. Biochem. 72: 248-254.

Brar, L. S., Walia, U. S. and Dhaliwal, B. K. 1999. Bio-efficacy of new herbicides for the control of resistant Phalaris minor in wheat. Pesticide Research Journal. 11: 177-180.

Chhokar, R.S. and Malik, R.K. 2002. Isoproturon-resistant little seed canarygrass (Phalaris minor) and its response to alternate herbicides. Weed Technol. 16:116-123.

Chhokar, R.S., Sharma, R.K., Chauhan, D.S., Mongia, A.D., 2006. Evaluation of herbicides against Phalaris minor in wheat in northwestern Indian plains. Weed Res. 46: 40-49.

Gill, H.S., Walia, U.S. and Brar, L.S. 1978. Control of Phalaris minor Retz. and wild oats in wheat with new herbicides. Pesticides. 12: 55-56. 
Havaux, M., Greppin, H. and Strasser, R. 1991. Functioning of photosystems I and II in pea leaves exposed to heat stress in the presence or absence of light. Planta. 186: 88-98.

Heath, R. L. and Packer, L. 1968. Photoperoxidation in isolated chloroplast. I. Kinetics and stochiometry of fatty acid peroxidation. Arch. Biochem. Biophys. 125: 189-198.

Hiscox, J. D. and Isralestam, G. S. 1979. A method for interaction of chlorophyll from leaf tissue without maceration. Canadian J. Bot. 57:1332-1334.

Kumar, D., Jayaswal, D., Jangra, A., Mishra, K. K. and Yadav, S. 2018. Recent approaches for herbicide resistance management in weeds: A review. International Journal of Chemical Studies. 6(4): 2844-2850.

Malik, R.K. and S. Singh. 1995. Littleseed canarygrass (Phalaris minor Retz.) resistance to isoproturon in India. Weed Technol. 9: 419-425.

Nash, D., Miyao, M. and Murata, N. 1985. Heat inactivation of oxygen evolution in photosystem II particles and its acceleration by chloride depletion and exogenous manganese, Biochim. Biophys. Acta (BBA) - Bioenergetics. 807: 127-133.

Norsworthy, J.K., Ward, S.M., Shaw, D.R., Llewellyn, R.S., Nichols, R.L., Webster, T.M., Bradley, K.W., Frisvold, G., Powles, S.B., Burgos, N.R., Witt, W.W., 2012. Reducing the risks of herbicide resistance: best management practices and recommendations. Weed Sci. 60: 31-62.

Petit, C., G. Bay, F. Pernin and C. Delye. 2010. Prevalence of cross-or multiple resistance to the acetyl-coenzyme A carboxylase inhibitors fenoxaprop, clodinafop and pinoxaden in black-grass (Alopecurus myosuroides Huds.) in France. Pest Manage. Sci. 66: 168-177.

Powles, S. B. and Gaines, T. A. 2016. Exploring the potential for a regulatory change to encourage diversity in herbicide use. Weed Sci. 64: 649-654.

Powles, S. B. and Yu, Q. 2010. Evolution in action: plants resistant to herbicides. Ann Rev Plant Biol. 61: 317-347.

Sairam, R. K., Deshmukh, P. S. and Shukla, D. S. 1997. Tolerance of drought and temperature stress in relation to increased antioxidant enzyme activity in wheat. J. Agron. Crop Sci. 178: 171177.

Swain, T. and Hillis, W. E. 1959. The phenolics constituents of Prunus domestica I. the quantitative analysis of phenolics constituents. J. Sci. Food Agric. 10: 63-68.

Tal, A., Zarka, S. and Rubin, B. 1996. Fenoxaprop-p resistance in Phalaris minor conferred by an insensitive acetyl-Coenzyme A carboxylase, Pestic. Biochem. Physiol. 56: 134-40.

Yadav, A., Malik, R. K. and Balyan, R. S. 1997. Studies on alternate herbicides to control isoproturon-resistant littleseed canary grass. Pestology. 21: 26-28.

\section{How to cite this article:}

Prinsa, Hem C. Joshi and Guru, S.K. 2018. Evaluation of Herbicidal Efficacy for Management of Isoproturon-Resistant Phalaris minor. Int.J.Curr.Microbiol.App.Sci. 7(12): 1067-1077. doi: https://doi.org/10.20546/ijcmas.2018.712.133 